\title{
Strategi Pembelajaran Quick on the Draw untuk Meningkatkan Aktivitas dan Hasil Belajar Mahasiswa Pada Materi Interpolasi
}

\author{
Septi Dariyatul Aini ${ }^{1}$, Sri Irawati ${ }^{2}$
}

1,2) Universitas Madura, Indonesia

Correspondence: $\square$ septi_math@unira.ac.id

\begin{tabular}{|c|c|}
\hline Article Info & Abstract \\
\hline $\begin{array}{l}\text { Article History } \\
\text { Received : 05-03-2019 } \\
\text { Revised : 20-05-2019 } \\
\text { Accepted : 15-06-2019 }\end{array}$ & $\begin{array}{l}\text { This research aims to determine the increase in student learning activities and } \\
\text { outcomes after being taught by using the quick on the draw learning strategy } \\
\text { in the interpolation material. This type of research is classroom action research } \\
\text { with a qualitative approach. This research was conducted at Madura }\end{array}$ \\
\hline $\begin{array}{l}\text { Keywords: } \\
\text { Interpolation; } \\
\text { Learning outcomes; } \\
\text { quick on the draw. }\end{array}$ & $\begin{array}{l}\text { University and those who were the subjects of the study were fourth semester } \\
\text { students of } 2017 / 2018 \text { academic year mathematics education. Data collection } \\
\text { techniques used are observation and test methods. From the data analysis it } \\
\text { can be concluded that: (1) student activity has increased from } 3.20 \text { (good } \\
\text { category) in the first cycle to } 3.76 \text { (excellent category) in the second cycle, (2) } \\
\text { student learning outcomes have increased from } 42.86 \text { in the first cycle then } \\
\text { increased to } 85.71 \% \text { in the second cycle. From the results of this study it can } \\
\text { be concluded that the application of quick on the draw learning strategies can } \\
\text { improve student learning activities and outcomes in interpolation material. }\end{array}$ \\
\hline
\end{tabular}

\section{PENDAHULUAN}

Metode numerik merupakan mata kuliah yang menyuguhkan metode-metode atau teknikteknik baru untuk memformulasikan masalah matematis melalui operasi hitung aritmatika (penjumlahan, pengurangan, perkalian, dan pembagian). Karena metode atau teknik yang dipelajari pada mata kuliah metode numerik ini baru bagi mahasiswa, tentu diperlukan keaktifan mahasiswa dalam memahami setiap teknik atau metode yang dipelajari sehingga bermakna dalam ingatan mahasiswa. Hal ini sesuai dengan pendapat Muhtadi, Hartono, dan Oktaviana [1] yang menyatakan bahwa suatu konsep akan lebih diingat dan dipahami apabila disajikan secara menarik dan melibatkan peserta didik secara aktif. Selain dibutuhkan keaktifan mahasiswa, ketelitian dan kecepatan dalam menjawab suatu pertanyaan sangat diperlukan dalam mata kuliah metode numerik khususnya pada materi interpolasi. Hal ini disebabkan karena penyelesaian yang diperoleh berupa pendekatan (menimbulkan galat/eror) serta membutuhkan proses iterasi yang cukup panjang.

Berdasarkan hasil pengamatan dan wawancara dengan dosen pengampu mata kuliah metode numerik di program studi pendidikan matematika Universitas Madura diketahui bahwa hampir 80\% mahasiswa cenderung pasif di kelas, tidak berani bertanya dan mengungkapkan pendapat secara lisan. Ini karena penyajian materi metode numerik khususnya pada materi interpolasi masih bersifat konvensional sehingga aktivitas mahasiswa saat perkuliahan sangat rendah karena hanya menerima materi yang disampaikan dosen tanpa ada kesempatan untuk menganalisis baik sebelum maupun sesudah penyajian materi. Ini mengakibatkan mahasiswa cenderung bosan karena pembelajaran kurang bermakna, tidak mandiri karena terbiasa pasif dan hanya menerima penjelasan 
dari dosen. Pada akhirnya berpengaruh terhadap hasil belajar mahasiswa yang masih sangat rendah dan hanya mencapai 30\% mahasiswa yang tuntas belajarnya. Hal ini pulalah yang melatarbelakangi penelitian Shoffa dan Suprapti [2] bahwa model pembelajaran langsung yang digunakan dalam perkuliahan metode numerik mengakibatkan mahasiswa bosan dan menganggap materi metode numerik sulit, sehingga bahan ajar jenis apapun belum mendukung sepenuhnya. Ini juga sejalan dengan pendapat Nurfitriyanti [3] yang menyatakan bahwa kreativitas dan kedisiplinan mahasiswa berpengaruh terhadap hasil belajar mahasiswa.

Untuk mengatasi rendahnya aktivitas dan hasil belajar mahasiswa pada materi interpolasi diperlukan penggunaan strategi pembelajaran yang tepat, salah satunya adalah strategi pembelajaran quick on the draw. Menurut Ginnis [4] strategi pembelajaran quick on the draw merupakan suatu strategi yang disetting dalam suasana permainan dan mengarahkan peserta didik untuk bekerja secara cepat di dalam kelompok. Penelitian sebelumnya membuktikan bahwa pembelajaran kelompok merupakan salah satu alternatif untuk meningkatkan hasil belajar siswa [5][6][7]. Strategi ini merangsang setiap mahasiswa dalam kelompok untuk aktif bekerjasama dalam memahami materi, menjawab pertanyaan, dan melaporkan jawaban yang diperoleh secara cepat dan tepat. Pembelajaran ini disetting dalam suasana perlombaan di mana kelompok yang paling cepat menyelesaikan soal-soal secara tepat maka kelompok tersebut menjadi kelompok pemenang. Kelebihan strategi pembelajaran quick on the draw ini yaitu: (1) menyadarkan mahasiswa pentingnya bekerja sama secara aktif dalam kelompok, melalui pembagian tugas dalam kelompok dan tidak hanya sekedar menyalin atau mencontoh; (2) terbiasa membaca dan menjawab pertanyaan secara hati-hati, cepat, dan tepat; (3) mampu membedakan materi yang penting dan tidak; (4) membiasakan mahasiswa belajar pada sumber, tidak menunggu penjelasan dosen. Oleh karena itu, melalui strategi pembelajaran quick on the draw yang disetting dalam suasana permainan dan menekankan mahasiswa untuk mengerjakan soal-soal secara cepat dan tepat, diharapkan mampu menciptakan suasana pembelajaran yang menyenangkan sehingga menimbulkan semangat belajar, serta meningkatkan aktivitas dan hasil belajar mahasiswa [4].

Berdasarkan uraian yang telah dikemukakan di atas, penerapan strategi pembelajaran quick on the draw dipandang efektif pada mata kuliah metode numerik materi interpolasi. Hal ini disebabkan karena materi interpolasi merupakan materi baru bagi mahasiswa sehingga membutuhkan aktivitas dan motivasi dalam diri mahasiswa. Selain itu, dengan membiasakan mahasiswa memahami materi dan mengerjakan soal-soal latihan secara mandiri mampu meningkatkan kepercayaan diri mahasiswa dan tidak bergantung pada orang lain. Karena alasan itulah, peneliti mencoba menerapkan strategi pembelajaran quick on the draw untuk meningkatkan aktivitas dan hasil belajar mahasiswa pada materi interpolasi. Adapun tujuan dari penelitian ini adalah untuk mengetahui peningkatan aktivitas dan hasil belajar mahasiswa setelah diajar dengan menggunakan strategi pembelajaran quick on the draw pada materi interpolasi.

\section{METODE PENELITIAN}

Penelitian ini merupakan penelitian tindakan kelas (PTK) yang dilaksanakan dalam beberapa siklus. Pada setiap siklus terdiri dari dua kali pertemuan di mana pada setiap pertemuan meliputi empat tahap kegiatan, yakni planning (perencanaan), acting (tindakan), observing (observasi), dan reflecting (refleksi). Setiap pertemuan akan diamati aktivitas yang dilakukan mahasiswa selama proses 
pembelajaran saat penerapan strategi pembelajaran quick on the draw, dan pada setiap dua pertemuan (setiap akhir siklus) akan dilakukan tes untuk melihat ketuntasan hasil belajar mahasiswa. Indikator keberhasilan penelitian ini adalah: (1) aktivitas mahasiswa mencapai kategori sangat baik; (2) mahasiswa yang mendapat skor $\geq 70$ paling sedikit $85 \%$ dari jumlah mahasiswa. Artinya, jika aktivitas mahasiswa mencapai kategori sangat baik dan mahasiswa yang mendapat skor $\geq 70$ paling sedikit $85 \%$ dari jumlah mahasiswa, maka pelaksanaan siklus dalam penelitian ini akan dihentikan karena penelitian ini dianggap telah berhasil meningkatkan aktivitas dan hasil belajar mahasiswa pada materi interpolasi. Subjek dalam penelitian ini adalah mahasiswa semester empat tahun akademik 2017/2018 sebanyak tujuh mahasiswa. Adapun materi perkuliahan metode numerik yang digunakan pada penelitian ini adalah interpolasi yang terdiri dari metode interpolasi linear dan kuadratik, metode newton, dan metode lagrange.

Penerapan strategi pembelajaran quick on the draw pada mata kuliah metode numerik materi interpolasi dilakukan dalam beberapa siklus, sampai penelitian ini berhasil. Gambaran mengenai kegiatan yang dilakukan pada setiap siklus dapat dilihat seperti yang ditampilkan pada Gambar 1.

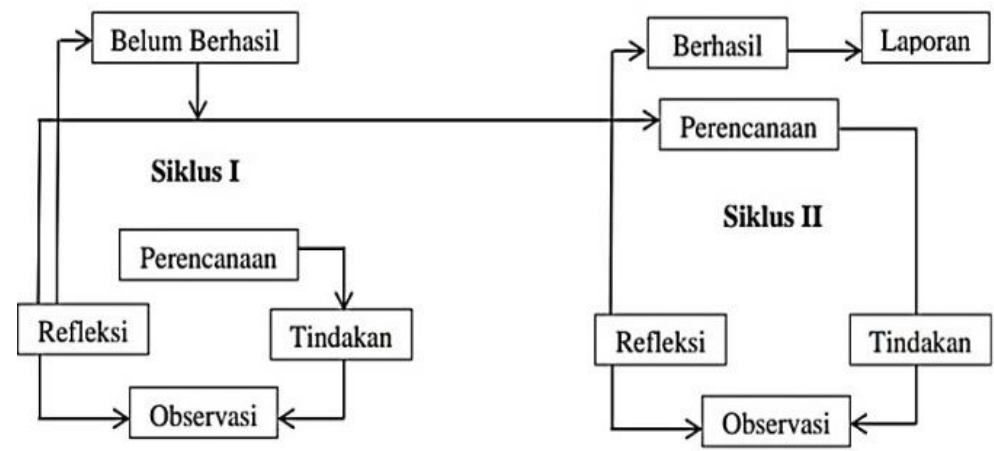

Gambar 1. Siklus Penelitian Tindakan Kelas (PTK)

Setiap siklus terdiri dari empat tahap yaitu perencanaan, tindakan, observasi, dan refleksi. Tahap perencanaan berkaitan dengan persiapan-persiapan sebelum penelitian dilakukan yaitu (1) menyusun perangkat pembelajaran berupa Rencana Pembelajaran Mingguan (RPM), Lembar Kerja Mahasiswa (LKM), materi sumber, set pertanyaan berupa kartu-kartu soal; (2) menyusun instrumen penelitian berupa lembar pengamatan aktivitas mahasiswa, dan soal tes; (3) Validasi perangkat pembelajaran dan instrumen penelitian oleh validator.

Tahap tindakan berkaitan dengan pelaksanaan penerapan strategi pembelajaran quick on the draw sesuai yang telah direncanakan. Adapun langkah-langkah kegiatan strategi pembelajaran quicke on the draw adalah terdiri dari kegiatan pendahuluan, inti dan penutup. Pada kegiatan pendahuluan, dosen melakukan apersepsi, menyampaikan tujuan pembelajaran, dan menjelaskan prosedur strategi pembelajaran quick on the draw. Pada kegiatan inti, dosen membagi mahasiswa ke dalam tiga kelompok heterogen, kemudian meminta mahasiswa berdiskusi dengan anggota kelompok terkait materi sumber yang telah diberikan. Setelah set pertanyaan telah disiapkan, dosen menjelaskan aturan pengambil an kartu soal, kemudian memberi aba-aba "mulai" kepada perwakilan tiap kelompok untuk mengambil kartu soal. Selanjutnya mahasiswa dalam setiap kelompok diminta untuk memecahkan masalah secara individu kemudian mendiskusikan hasil kerjanya dengan kelompok. Aktivitas selanjutnya adalah dosen meminta masing-masing kelompok menuliskan hasil diskusi pada LKM untuk selanjutnya dikumpulkan dan diperiksa dosen. Jika 
jawaban benar, maka mahasiswa boleh mengambil kartu selanjutnya, dan jika jawaban kartu salah, maka harus memperbaki dan mendiskusikan kembali jawabannya. Kelompok yang pertama menjawab semua (satu set) pertanyaan sampai selesai sebagai dinyatakan sebagai kelompok pemenang. Pada kegiatan penutup dosen melakukan evaluasi dengan memberikan tes, meminta mahasiswa untuk membuat kesimpulan, memberikan informasi terkait materi selanjutnya, dan mengakhiri pembelajaran dengan mengucapkan salam penutup.

Tahap observasi berkaitan dengan pengamatan proses pembelajaran di kelas dengan menggunakan lembar observasi yang telah dibuat. Observasi ditekankan pada tingkat penguasaan mahasiswa terhadap materi dan seberapa jauh pelaksanaan tindakan dapat menghasilkan perubahan yang diinginkan. Tujuan kegiatan observasi adalah untuk memperoleh informasi aktivitas belajar mahasiswa dalam kelompok dan pengelolaan kelas selama proses pembelajaran.

Tahap refleksi berkaitan dengan evaluasi hasil tindakan yang telah dilakukan dengan cara melakukan penilaian terhadap proses yang ter jadi, mencermati masalah-masalah yang muncul, serta hal-hal lain yang berkaitan dengan pelaksanaan tindakan. Kegiatan refleksi juga sekaligus berusaha mencari jalan keluar terhadap masalah yang terjadi. Hasil refleksi digunakan sebagai masukan dalam menyusun rancangan tindakan berikutnya sekaligus menyusun kesimpulan terhadap hasil setiap siklus.

Siklus II dilaksanakan sebagai perbaikan dari siklus I, terutama jika terjadi kekurangan dalam perencanaan dan tindakan pada siklus I. Siklus II juga terdiri dari empat tahap yaitu perencanaan, tindakan, observasi, dan refleksi. Keputusan untuk melanjutkan atau menghentikan penelitian tergantung pada hasil refleksi yang dilakukan pada akhir setiap siklus penelitian. Apabila hasil refleksi terhadap siklus II menunjukkan bahwa proses dan hasil pembelajaran yang dilakukan oleh peneliti mengalami peningkatan hasil dari siklus I sampai siklus II maka tindakan dihentikan, akan tetapi apabila masih belum maka tindakan dilanjutkan sampai siklus berikutnya.

Instrumen yang digunakan dalam penelitian ini meliputi: (1) lembar observasi aktivitas mahasiswa, dan (2) tes hasil belajar. Teknik pengumpulan data yang digunakan adalah metode observasi, dan tes. Dalam penelitian ini metode observasi yang digunakan adalah observasi sistematis dengan menggunakan pedoman sebagai instrumen pengamatan. Keterlaksanaan aktivitas mahasiswa selama proses pembelajaran diberi rentang skor 0 sampai 4 . Selanjutnya, tes yang diberikan berupa soal essay untuk mengetahui ketuntasan hasil belajar secara individual dan klasikal.

Teknik analisis data dalam penelitian ini meliputi analisis data hasil observasi dan analisis data hasil tes. Analisis data hasil observasi berupa penilaian hasil observasi aktivitas mahasiswa pada mata kuliah metode numerik materi interpolasi dengan menggunakan strategi pembelajaran quick on the draw, peneliti menggunakan rumus menurut Arikunto [9] berikut:

$$
\mathrm{NA}=\frac{\sum n}{\sum a}
$$

Keterangan:

NA $=$ Nilai akhir

$\mathrm{n} \quad=$ Nilai setiap aspek yang diamati

$a \quad=$ Aspek yang diamati

Dengan kategori penentuan nilai 
akhir (NA) yaitu: $0,00 \leq \mathrm{NA} \leq 1,49$ kategori kurang; $1,50 \leq \mathrm{NA} \leq 2,49$ kategori cukup; 2,50 $\leq$ $\mathrm{NA} \leq 3,49$ kategori baik; 3,50 $\leq \mathrm{NA} \leq 4,00$ kategori sangat baik.

Sedangkan analisis data hasil tes berupa peningkatan hasil belajar mahasiswa yang dapat dilihat dari hasil tes yang dilakukan setelah pembelajaran menggunakan strategi pembelajaran quick on the draw (pada setiap akhir siklus). Seorang mahasiswa secara individu dikatakan tuntas belajarnya apabila ia memperoleh nilai minimal 70 . Suatu kelas dikatakan tuntas secara klasikal apabila mahasiswa yang mendapat skor $\geq 70$ paling sedikit $85 \%$ dari jumlah mahasiswa. Untuk menghitung ketuntasan belajar klasikal, peneliti menggunakan rumus menurut Trianto [10] berikut:

$$
\mathrm{KBK}=\frac{\text { jumlah siswa yang tuntas }}{\text { jumlah seluruh siswa }} \times 100 \%
$$

\section{HASIL DAN PEMBAHASAN}

Berdasarkan penelitian yang dilakukan selama dua siklus ditemukan data tentang hasil observasi aktivitas mahasiswa, dan hasil tes belajar mahasiswa. Aktivitas mahasiswa mengalami peningkatan. Pada siklus I berada pada kategori "baik" dengan skor sebesar 3,20, sedangkan pada siklus II aktivitas mahasiswa mengalami peningkatan yaitu berada pada "sangat baik" dengan skor sebesar 3,76 .

Hasil belajar mahasiswa juga mengalami peningkatan. Pada siklus I dengan jumlah mahasiswa yang tuntas sebanyak 3 orang dan mahasiswa yang tidak tuntas sebanyak 4 orang, sedangkan pada siklus II dengan jumlah mahasiswa yang tuntas sebanyak 6 orang dan mahasiswa yang tidak tuntas sebanyak 1 orang. Adapun ketuntasan belajar klasikal mahasiswa pada siklus I mencapai 42,86\%, meningkat pada siklus II menjadi 85,71\%.

Peningkatan aktivitas dan hasil belajar mahasiswa dari siklus I ke siklus II berturut-turut ditunjukkan oleh gambar 2 dan gambar 3 berikut. 


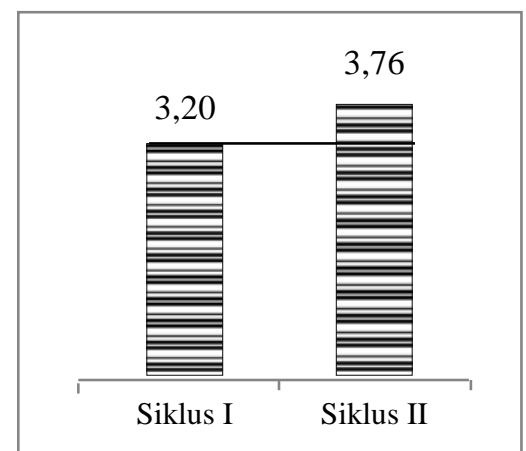

Gambar 2. Peningkatan Aktivitas Mahasiswa

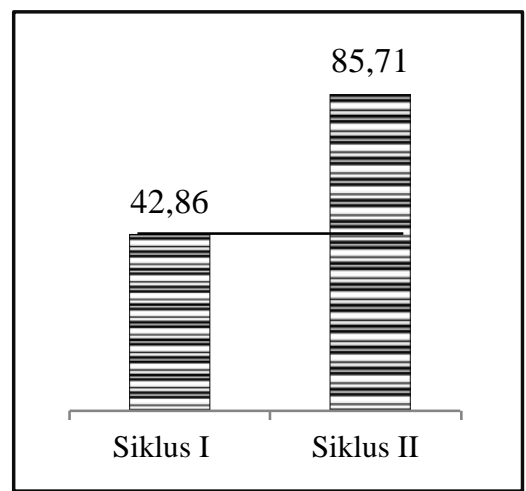

Gambar 3. Peningkatan Hasil Belajar Mahasiswa

Berdasarkan hasil temuan penelitian tersebut, diperoleh data bahwa ada perbedaan aktivitas dan hasil belajar mahasiswa antara siklus I dan siklus II. Pada siklus I, masih belum maksimal dalam peningkatan aktivitas dan hasil belajar mahasiswa, terlihat pada hasil observasi aktivitas mahasiswa dan hasil rata-rata tingkat penguasaan kompetensi mahasiswa secara berturut-turut mencapai 3,20 dan 42,86\%. Pada siklus II tampak suatu perbaikan yang sudah dilakukan oleh peneliti untuk meningkatkan aktivitas dan hasil belajar mahasiswa, terlihat pada hasil observasi aktivitas mahasiswa dan hasil rata-rata tingkat penguasaan kompetensi mahasiswa secara berturut-turut mencapai 3,76 dan 85,71\% dan sudah mencapai indikator keberhasilan dari penelitian ini. Sehingga aktivitas dan hasil belajar mahasiswa pada mata kuliah metode numerik materi interpolasi dengan menggunakan strategi pembelajaran quick on the draw mengalami peningkatan.

Pada kegiatan awal, dosen membuka pelajaran dengan mengucapkan salam dan melakukan presensi. Selanjutnya dosen melakukan apersepsi yaitu mengaitkan materi yang akan dipelajari tentang interpolasi dengan fungsi dan persamaan yang pernah mereka dapatkan saat di tingkat sekolah menengah. Berdasarkan pertanyaan pancingan dari dosen, sebagian besar mahasiswa sudah lupa dengan materimateri tersebut. Selanjutnya dosen menyampaikan tujuan pembelajaran dan menjelaskan prosedur penerapan strategi pembelajaran quick on the draw pada seluruh mahasiswa, namun masih ada beberapa mahasiswa yang berbicara sendiri dan tidak memperhatikan penjelasan dosen.

Pada kegiatan inti, dosen membagi mahasiswa ke dalam tiga kelompok heterogen berdasarkan skor awal nilai kuis (ulangan) pada bab sebelumnya, dimana masing-masing kelompok terdiri dari 2 atau 3 
mahasiswa. Setiap mahasiswa dari tiap kelompok diberi materi sumber tentang interpolasi dengan menggunakan metode interpolasi linear dan kuadratik sebagai panduan bagi mahasiswa pada saat mengerjakan pertanyaan-pertanyaan yang terdapat pada kartu soal. Dosen meminta mahasiswa memahami dan berdiskusi dengan anggota kelompok terkait materi sumber yang telah diberikan. Dosen melakukan tanya jawab seperlunya atau memberikan pertanyaan pancingan dengan mahasiswa jika kesulitan dalam memahami materi sumber, namun mahasiswa cenderung diam, ragu, dan malu untuk bertanya ataupun menjawab pertanyaan dosen. Selanjutnya dosen menyiapkan 3 set pertanyaan sesuai jumlah kelompok. Setiap set pertanyaan tersebut terdiri dari 3 kartu soal dan diberi warna berbeda yaitu merah, kuning, dan hijau sesuai nama tiap kelompok. Setiap kelompok nantinya akan mengambil kartukartu soal pada set pertanyaan dengan warna yang sama dengan nama kelompok.

Setelah semua mahasiswa berada pada kelompok masing-masing dan mendapat materi sumber serta set-set pertanyaan telah dipersiapkan diatas meja dosen, maka dosen menjelaskan aturan pengambilan kartu soal pada set pertanyaan, kemudian memberi aba-aba "mulai" kepada perwakilan tiap kelompok untuk mengambil kartu soal. Selanjutnya mahasiswa dalam setiap kelompok diminta untuk mengerjakan kartu soal secara individu kemudian mendiskusikan hasil kerjanya dengan kelompok. Pada tahap pengerjaan kartu soal secara individu ini, masih terlihat beberapa mahasiswa saling bekerja sama dengan anggota kelompoknya. Sebagian besar mahasiswa juga belum terbiasa mengerjaan secara cepat dan teliti. Hal ini dapat disebabkan karena mahasiswa kurang lihai menghitung dengan alat bantu kalkulator; kurang mempersiapkan alat-alat yang dibutuhkan untuk proses pengerjaan kartu soal seperti kalkulator dan penggaris. Aktivitas selanjutnya adalah dosen meminta masing-masing kelompok menuliskan hasil diskusi pada LKM untuk selanjutnya dikumpulkan dan diperiksa dosen. Jika jawaban benar, maka perwakilan kelompok boleh mengambil kartu selanjutnya, dan jika jawaban kartu salah, maka harus memperbaki dan mendiskusikan kembali jawabannya. Kelompok yang pertama menjawab semua (satu set) pertanyaan sampai selesai dinyatakan sebagai kelompok pemenang. Pada akhir kegiatan inti, dosen bersama mahasiswa membahas jawaban kartu-kartu soal dan membuat catatan tertulis.

Pada kegiatan penutup, dosen melakukan evaluasi untuk menguji tingkat pemahaman mahasiswa pada materi interpolasi dengan menggunakan metode interpolasi polinomial umum dan metode newton dengan memberikan tes berupa soal essay sebanyak 3 butir soal dalam waktu 60 menit. Sebagian besar mahasiswa mengeluh karena alokasi waktu yang diberikan tidak cukup untuk menjawab ketiga butir soal tersebut. Pada tahap ini pula masih terlihat beberapa mahasiswa kesulitan dalam mengerjakan soal nomor 2 dan 3. Tahap selanjutnya dosen meminta mahasiswa menyimpulkan materi yang telah dipelajari. Akan tetapi, masih ada beberapa mahasiswa belum menyimpulkan secara tepat. Kemudian dosen menutup pelajaran dan mengingatkan mahasiswa untuk mempelajari materi interpolasi dengan menggunakan metode newton dan lagrange.

Berdasarkan hasil penelitian pada siklus I diperoleh data aktivitas mahasiswa 3,20 (kategori baik) dan hasil belajar mahasiswa (tes siklus I) belum mencapai ketuntasan belajar klasikalyaitu hanya 42,86\%. Artinya, pada siklus I ini masih belum mencapai indikator keberhasilan dalam penelitian ini. Hal ini disebabkan karena kelemahan-kelemahan yang muncul pada siklus I yaitu masih ada beberapa mahasiswa yang berbicara sendiri dan kurang antusias mengikuti pelajaran; pada saat pengerjaan kartu soal secara individu ada beberapa mahasiswa yang saling bekerja sama; kurang cepat dan kurang teliti dalam proses pengerjaan; kurang lihai menghitung dengan alat bantu kalkulator; kurang mempersiapkan alat-alat yang dibutuhkan untuk proses pengerjaan kartu soal dan tes seperti kalkulator dan penggaris, serta kurangnya alokasi waktu yang disediakan untuk pengerjaan tes.

Upaya yang dilakukan peneliti untuk meminimalisir kelemahan-kelemahan yang terjadi pada siklus 
I serta memperbaikinya agar tidak terulang kembali pada siklus II sehingga mampu mencapai hasil penelitian seperti yang diharapkan adalah dosen harus sering memotivasi mahasiswa untuk lebih teliti dan lebih cepat dalam melakukan perhitungan dan penulisan jawaban kartu-kartu soal karena kelompok yang mampu menyelesaikan kartu-kartu soal lebih awal akan menjadi pemenang dan mendapat hadiah serta tambahan nilai; dosen memberikan teguran/nasehat dan hukuman berupa pengurangan nilai untuk mahasiswa yang kurang memperhatikan; pada saat pengerjakan kartu soal secara individu diperlukan pengawasan dari dosen dengan 2 observer untuk meminimalisir kerja sama antar anggota kelompok; dosen perlu melakukan apersepsi berupa arahan dan bimbingan dalam memperkirakan suatu nilai dalam rentang data yang diketahui; memberikan cara penghitungan dengan alat bantu kalkulator secara cepat dan tepat; mengingatkan mahasiswa untuk lebih teliti dalam proses pengerjaan kartu-kartu soal dan tes; untuk menghemat waktu, dosen mengurangi jumlah butir soal tes, mengingatkan mahasiswa untuk membawa alat tulis yang dibutuhkan dalam mengerjakan kartu soal dan tes seperti kalkulator dan penggaris, menyesuaikan alokasi waktu tes dengan tingkat kesulitan soal tes dan waktu minimal yang dibutuhkan mahasiswa untuk mengerjakan kartu soal secara individu.

Pada kegiatan awal, dosen membuka pelajaran dengan mengucapkan salam dan melakukan presensi. Selanjutnya dosen melakukan apersepsi dengan mengaitkan materi yang akan dipelajari tentang interpolasi metode newton dan lagrange dengan interpolasi metode linear dan kuadratik yang telah dipelajari pada pertemuan sebelumnya. Pada tahap apersepsi ini, dosen juga memberikan arahan dan bimbingan berupa pertanyaan pancingan pada mahasiswa terkait penggunaan kalkulator secara cepat dan tepat sehingga membantu dalam proses penghitungan kartu soal. Dosen juga berusaha memotivasi mahasiswa untuk lebih teliti dan lebih cepat dalam melakukan perhitungan dan penulisan jawaban kartu-kartu soal karena kelompok yang mampu menyelesaikan kartu-kartu soal lebih awal akan menjadi pemenang dan mendapat hadiah serta tambahan nilai. Hal ini mendapat respon positif dari mahasiswa, terlihat mahasiswa antusias dan termotivasi mendengarkan penjelasan dosen pada saat menjelaskan tujuan pembelajaran dan prosedur penerapan strategi pembelajaran quick on the draw pada seluruh mahasiswa.

Pada kegiatan inti, dosen membagi mahasiswa ke dalam tiga kelompok heterogen. Anggota kelompok yang terbentuk pada siklus II ini berbeda dengan anggota kelompok pada siklus I, hal ini dimaksudkan agar mahasiswa terbiasa berinteraksi dan berkerja sama tanpa membedakan ras/gender/karakter/status sosial ekonomi. Setiap mahasiswa dari tiap kelompok diberi materi sumber tentang interpolasi dengan menggunakan metode newton dan lagrange sebagai panduan bagi mahasiswa pada saat mengerjakan pertanyaan-pertanyaan yang terdapat pada kartu soal. Dosen meminta mahasiswa memahami dan berdiskusi dengan anggota kelompok terkait materi sumber yang telah diberikan. Dosen melakukan tanya jawab seperlunya atau memberikan pertanyaan pancingan dengan mahasiswa jika kesulitan dalam memahami materi sumber. Selanjutnya dosen menyiapkan 3 set pertanyaan sesuai jumlah kelompok. Setiap set pertanyaan tersebut terdiri dari 3 kartu soal dan diberi warna berbeda yaitu merah, kuning, dan hijau sesuai nama tiap kelompok. Setiap kelompok nantinya akan mengambil kartu-kartu soal pada set pertanyaan dengan warna yang sama dengan nama kelompok.

Setelah semua mahasiswa berada pada kelompok masing-masing dan mendapat materi sumber serta set-set pertanyaan telah dipersiapkan diatas meja dosen, maka dosen menjelaskan aturan pengambilan kartu soal pada set pertanyaan, kemudian memberi aba-aba "mulai" kepada perwakilan tiap kelompok untuk mengambil kartu soal. Selanjutnya mahasiswa dalam setiap kelompok diminta untuk mengerjakan kartu soal secara individu kemudian mendiskusikan hasil kerjanya dengan kelompok. Pada tahap pengerjaan kartu soal secara individu ini terlihat mahasiswa mengerjakan secara mandiri tanpa bekerja sama ataupun meminta bantuan anggota kelompok disebelahnya. Mahasiswa juga sudah mampu 
mengerjaan kartu soal secara cepat dan teliti, bahkan ada beberapa mahasiswa yang selesai mengerjakan sebelum waktu yang ditentukan. Hal ini dapat disebabkan karena mahasiswa sudah terbiasa mengerjakan soal secara cepat dan tepat, lihai menggunakan kalkulator, serta tersedianya alat-alat yang dibutuhkan untuk proses pengerjaan kartu soal seperti kalkulator dan penggaris. Aktivitas selanjutnya adalah dosen meminta masing-masing kelompok menuliskan hasil diskusi pada LKM untuk selanjutnya dikumpulkan dan diperiksa dosen. Jika jawaban benar, maka perwakilan kelompok boleh mengambil kartu selanjutnya, dan jika jawaban kartu salah, maka harus memperbaki dan mendiskusikan kembali jawabannya. Kelompok yang pertama menjawab semua (satu set) pertanyaan sampai selesai dinyatakan sebagai kelompok pemenang serta mendapat hadiah dan tambahan nilai dari dosen.Pada akhir kegiatan inti, dosen bersama mahasiswa membahas jawaban kartu-kartu soal dan membuat catatan tertulis.

Pada kegiatan penutup, dosen melakukan evaluasi untuk menguji tingkat pemahaman mahasiswa pada materi interpolasi dengan menggunakan metode newton dan lagrange dengan memberikan tes berupa soal essay sebanyak 2 butir soal dalam waktu 50 menit. Pada tahap pengerjaan tes ini, dosen mengingatkan mahasiswa kembali untuk lebih teliti dan memeriksa kembali jawaban yang diperoleh. Hal ini memberikan dampak positif karena beberapa mahasiswa selesai mengerjakan soal tes kurang dari 50 menit dan sudah tidak ada lagi mahasiswa yang nampak kesulitan dalam mengerjakan kedua butir soal tes tersebut. Tahap selanjutnya dosen meminta mahasiswa menyimpulkan materi yang telah dipelajari. Terlihat bahwa mahasiswa sudah mampu menyimpulkan secara tepat. Kemudian dosen menutup pelajaran dan mengingatkan mahasiswa untuk mempelajari materi interpolasi dengan menggunakan metode newton gregory maju-mundur

Akhirnya, perbaikan pada siklus II terlaksana secara maksimal karena aktivitas mahasiswa 3,76 (kategori sangat baik), dan hasil belajar mahasiswa memenuhi kriteria ketuntasan secara klasikal sebesar 85,71\%. Pada siklus II ini mahasiswa antusias dan termotivasi untuk mengikuti pelajaran; mandiri dan tidak saling kerja sama saat pengerjaan kartu soal secara individu; mampu melakukan interpolasi secara tepat; lihai menghitung dengan alat bantu kalkulator; lebih teliti dan lebih cepat mengerjakan kartu-kartu soal ataupun tes bahkan ada mahasiswa yang selesai sebelum waktu yang ditentukan, serta mempersiapkan segala sesuatunya sebelum pembelajaran dimulai, seperti kalkulator, penggaris, dan alat penunjang pembelajaran lainnya.

Dari keseluruhan kegiatan yang telah dilaksanakan, tujuan penelitian telah tercapai pada siklus II. Oleh karena itu, penelitian dianggap selesai dan hasil penelitian menunjukkan bahwa penerapan strategi pembelajaran quick on the draw dapat meningkatkan aktivitas dan hasil belajar mahasiswa pada materi interpolasi. Hasil ini relevan dengan beberapa hasil penelitian terdahulu. Hasil penelitian Aini [11] menyimpulkan bahwa pembelajaran dengan pendekatan pembelajaran visual thinking disertai aktivitas quick on the draw mampu meningkatkan hasil belajar mahasiswa pada mata kuliah metode numerik pokok bahasan akar persamaan tak linear. Beberapa hasil penelitian lain juga mengungkapkan adanya perbedaan signifikan hasil belajar antara sebelum dan setelah pembelajaran quick on the draw [12]. Selain itu, hasil penelitian lainnya memberikan hasil bahwa pembelajaran quick on the draw dalam proses pembelajaran mampu meningkatkan aktivitas peserta didik [13].

\section{SIMPULAN DAN SARAN}

Berdasarkan analisis data yang diuraikan sebelumnya, dapat disimpulkan bahwa aktivitas mahasiswa selam proses pembelajaran menggunakan strategi pembelajaran quick on the draw pada mata kuliah metode numerik materi interpolasi menunjukkan adanya peningkatan yaitu dari 3,20 (kategori baik) pada siklus I meningkat menjadi 3,76 (kategori sangat baik) pada pada siklus II. Sedangkan hasil belajar mahasiswa 
dalam penggunaan strategi pembelajaran quick on the draw pada mata kuliah metode numerik materi interpolasi juga menunjukkan adanya peningkatan yaitu dari 42,86\% (belum tuntas secara klasikal) pada siklus I meningkat menjadi $85,71 \%$ (tuntas secara klasikal) pada siklus II.

Dari simpulan tersebut, maka peneliti menyarankan beberapa hal berikut: (1) perangkat pembelajaran pada strategi pembelajaran quick on the draw hendaknya digunakan oleh dosen khususnya di program studi pendidikan matematika pada materi-materi perkuliahan yang memerlukan peran aktif mahasiswa dalam upaya meningkatkan hasil belajarnya; (2) dalam menerapkan strategi pembelajaran quick on the draw ini sebaiknya dosen selalu memotivasi mahasiswa dalam kelompok agar berperan secara aktif dan kooperatif dalam memahami materi sumber dan menyelesaikan kartu-kartu soal; (3) sebelum melaksanakan pembelajaran, dosen harus memperhitungkan alokasi waktu pembelajaran dengan baik agar penerapan strategi pembelajaran quick on the draw ini tidak melebihi batas waktu perkuliahan yang telah ditetapkan.

\section{DAFTAR PUSTAKA}

[1] M. Muchtadi, H. Hartono, and D. Oktaviana, "Hubungan Aktivitas dan Respon terhadap Hasil Belajar Program Linier Setelah Diterapkan Pembelajaran Genius Learning pada Program Studi Pendidikan Matematika," Edu Sains J. Pendidik. Sains Mat., vol. 5, no. 1, pp. 45, Sep. 2017.

[2] S. Shoffa and E. Suprapti, "Peningkatan Hasil Belajar Mahasiswa pada Mata Kuliah Metode Numerik dengan Model Pembelajaran Kooperatif Jigsaw," MUST J. Math. Educ. Sci. Technol., vol. 2, no. 2, pp. 178-188, Sep. 2017.

[3] M. Nurfitriyanti, "Pengaruh Kreativitas Dan Kedisiplinan Mahasiswa Terhadap Hasil Belajar Kalkulus," Form. J. Ilm. Pendidik. MIPA, vol. 4, no. 3, Aug. 2015.

[4] P. Ginnis, Trik dan taktik mengajar. Jakarta: PT. Indeks, 2008.

[5] M. Kuslaila, E. F. Ningsih, and W. Kusumaningtyas, "Eksperimentasi Model Pembelajaran Pair Checks Pada Materi Pokok Segitiga Ditinjau Dari Gaya Belajar Peserta Didik," JIPMat, vol. 2, no. 2, Dec. 2017.

[6] C. Zahra, S. Widyawati, and E. F. Ningsih, "Eksperimentasi Model Pembelajaran Kooperatif Tipe Student Facilitator And Explaining (SFE) Berbantuan Alat Peraga Kotak Imajinasi Ditinjau Dari Kecerdasan Spasial," JIPMat, vol. 2, no. 2, Dec. 2017.

[7] R. Fahrullisa, F. G. Putra, and N. Supriadi, "Pengaruh Model Pembelajaran Kooperatif Tipe Think Pair Share (TPS) berbantuan Pendekatan Investigasi terhadap Kemampuan Komunikasi Matematis," Numer. J. Mat. dan Pendidik. Mat., pp. 145, Dec. 2018.

[8] K. E. Lestari and M. R. Yudhanegara, Penelitian Pendidikan Matematika. Karawang: Refika Aditama, 2017.

[9] S. Arikunto, Prosedur Penelitian Suatu Pendekatan Praktek. Jakarta: Rineka Cipta, 2010.

[10] Trianto, Mendesain Model Pembelajaran Inovatif Progresif. Surabaya: Kencana Perdana Media Group, 2009.

[11] S. D. Aini and S. Irawati, "Meningkatkan hasil belajar mahasiswa melalui pembelajaran visual thinking disertai aktivitas quick on the draw," Pythagoras J. Pendidik. Mat., vol. 12, no. 2, pp. 210 219, Dec. 2017.

[12] D. P. Ariyamti, Iin dan Sari, "Implementasi Model Pembelajaran Kooperatif Tipe Quick on the 
Numerical: Jurnal Matematika dan Pendidikan Matematika, 1(1), Juni 2019, 19-30

Septi Dariyatul Aini, Sri Irawati

Draw pada Mata Pelajaran Matematika di SMPN 6 Banjarmasin Tahun Pelajaran 2012-2013," in Seminar Nasional Matematika dan Pendidikan Matematika, 2015, pp. 1047-1054.

[13] A. I. Lestiyaningsih, H., Hobri, H., \& Kristiani, "Penerapan pembelajaran quick on the draw untuk meningkatkan hasil belajar matematika pada sub pokok bahasan aritmetika sosial siswa kelas VII F semester ganjil SMP Negeri 10 Jember," J. KADIKMA, pp. 43-46, 2013. 
Numerical: Jurnal Matematika dan Pendidikan Matematika, 1(1), Juni 2019, 19-30 Septi Dariyatul Aini, Sri Irawati

[Halaman ini sengaja dikosongkan] 